\title{
Tunisian validation of a measuring instrument: Physical Self- Description Questionnaire (PSDQ)
}

\author{
Abdelaziz Hentati ${ }^{1}$, Ali Elloumi ${ }^{2}$ \\ ${ }^{1}$ Higher Institute of Sport and Physical Education of Sfax (Tunisia) \\ ${ }^{2}$ Faculty of Letters and Humanities of Sfax (Tunisia)
}

\begin{abstract}
This article is part of work aiming Tunisian validation of measurement scales on the motivation of individuals in the context of sport, with executives from analysis of the socio-cognitive and emotional contemporary and theoretical background which represents the cultural adaptation of measuring instruments. This work focuses on validation in context, in Arabic, of the -Physical Self-Description Questionnaire (PSDQ) (Marsh et al., 1994), from French version that was performed by Guérin et al. (2004). In the absence of psychometric instruments constructed from a sample Tunisian transcultural validation is recommended to assess the role of culture in determining motivational behaviors related to athletic performance. In addition, such work can avoid the profusion of similar tools that capture the same concepts (cf. RJ Vallerand, 1989). This tool, the PSDQ contains a wide range of scales designed to assess self-perceptions through nine specific dimensions and two global components: satisfaction overall physical and global self-esteem. 430 subjects (216 boys and 214 girls) responded to 70 items of PSDQ and correlation matrices were subjected to principal analysis components with varimax orthogonal rotation.

Following the adopted approach by Guerin et al (2004), we find for the Arabic version of the 11dimensional structure, overall self-esteem, self-concept from general physical inventory of Marsh (1996) and other scales measured (health, coordination, physical activity, overweight, athletic competence, appearance, strength, flexibility and endurance), with a very good internal consistency. When each dimension was independently subjected to factor analysis, although we found the same 11 dimensions as in the original instrument Marsh (1996) as a psychometric point of view and conceptually one.
\end{abstract}

Keywords - self-concept, global physical satisfaction, global self-esteem, validation, Tunisian culture

\section{Introduction}

The orientation towards sports competition appears to be the result of a process where interfere two systems of representation: first representations of the world of sports and other self-representation. With reference to Ricœur (2005), "the self is always thoughtful, he is always in the second degree, first degree being precisely the passage from the outside" (p. 7); so is he as an instance in part informed by the culture. It is from this dialectic that is born and develop in young self-projection into the future in harmony with its environment and is predictive of the likelihood of success in sports competition.

Good related to the possession of a measure tool culturally relevant, encourage us, in the present work, to undertake an analysis whose goal is the adaptation to the Tunisian context, the French version (Famose and Guerin, 2001) of PSDQ (Physical Self Description Questionnaire) originally proposed by Marsh (1994), following a current research very widespread in recent years which the object is the transcultural validation of psychological questionnaires. In addition, as advised elsewhere Vallerand (1989), the formation of psychological instruments, it is recommended that in the absence of reliable and valid tools in the international literature.

On the epistemological level, we cannot afford to incorporate in a particular context, research instruments designed and validated within a given culture, knowing the likely differences that exist between the two groups. Also agree to adopt such positions in research on psychosocial determinants of athletic performance, would be conceived as invariant and universal human psyche. Say that the Self, for example, is a concept that covers the manner in which an individual tends to know and react emotionally, suppose that the construction of beliefs about the self unfolds in reflexivity (Habermas, 1976, Bourdieu, 1992) and a dynamic and dialectical social environment. The consequences of this precision implies not only the need to articulate the individual and the social, but also the individual to the culture. Psychologists must not forget how culture could condition the mind. Camilleri (1996) develops the idea of the cultural roots of the individual personality: "all the subject's behavior, he says, and their products, but also what it receives and assimilates can be informed by the culture" (p. 13).

The arguments are all the more justified than the body, description object in the questionnaire that we will validate, is not a cultural invariant, but crossed through by the culture. It is, as shown Jodelet (1992), "a 
subject about which manifests itself most profoundly characteristic of personal identity and the internalization of social" (p. 160). This phenomenological perspective of the body (Merleau-Ponty, 1976) develops the idea of the radical subjectivity: it is both incorporation or internalization of the world (the world in itself) and incarnation in the world (the world itself). Recalling the cultural reality of the body, we can see how important the impact of social symbolism on the formation of beliefs about the physical self, predictive motivations of subjects on their choice, the strength and durability of their involvement in the sport.

What is the impact of Tunisian culture having on the perception of the body and physical self-concept? It is for the validation work to answer this question; but to achieve this, it is necessary to: 1) explain the different visions of the body that emerge from the Physical Self-Description Questionnaire from the nine specific dimensions and its two components overall evaluative and affective, 2) develop a framework that allows notional decipher the impact of Tunisian culture on the perception of the body, to interpret the results of the investigation into the validation of PSDQ. These two elements constitute the conceptual framework of this article.

\section{Conceptual framework of the research}

\section{1 - The physical self-concept:}

It is one of the sub-areas of global self-concept; it reflects the participation of the corporal dimension to the construction and structure of global self-concept. One can easily imagine the impact on the strengthening or weakening of self-esteem. A satisfactory perception and perpetual investment of their bodies promote the wellbeing of children, just as they facilitate interactive relationships with others.

With reference to a study of Harter (1987), Famose (2000) notes that among the observed relationships between the various self assessments specific (academic competence, athletic competence, social acceptance, physical appearance and behavioral conduct) and self-esteem, that relating to physical appearance is most strongly correlated with self-esteem.

The most current version of the physical self-concept proposed by Marsh et al. (1994); she comes across nine specific dimensions: strength, corpulence (overweight), physical activity, endurance, sports skills, coordination, health, physical appearance, flexibility and two global components: satisfaction overall physical and global self-esteem.

In their formulation, the items constituting the different dimensions of physical self-concept, each one has a connotation between a positive pole appreciated and a negative pole depreciated, in relation to the pursuit of sports projects; Clarifying the implicit meaning of the different dimensions of the body of the questionnaire is essential to show the similarities and differences in perceptions of physical self-concept between the original building and built to validate a Tunisian population of Arab-Muslim culture. Indeed, PSDQ remains bound to the specific context in which it was built and / or validated, that is to say, it characterizes some companies, namely, Australia and France.

We distinguish three ideal types (Weber, 1965) meanings: the first is suggested by the emphasis on body control which gives mainly a spatial conception, expressed by relations of objectification, profitability and instrumentalization. What is important is to have a body available, ready to use. This results in a failure of the subject "with itself (have a body more being body "(Le Breton, 1990, p. 8).

The second ideal type indicates that the body, as noted by Le Breton (cited by Duret et al., 2002, p. 20), "as a factor of individuation and instrument separation between self and other, specific modern societies." Thus, the body involves a second cut, that of the subject with others. The third ideal type finally reveals a "contemporary dualism that opposes man's body" (Le Breton, 1990, p. 9). In the words of the same author, the body has become the alter ego of man "privileged place of well-being (form), well-published (forms, bodybuilding, cosmetic, dietary, etc...) passion of effort (marathon, jogging, windsurfing) or risk (climbing, "adventure", etc.)" (p. 9).

Our intention is to ensure that the interpretation of the different dimensions composing the physical self-concept in a confined sociocognitivist explanation of human behavior, but also takes into account the data of anthropology of the body; such analyzes can approach with relevance, the question of the body in the Tunisian culture.

\section{2 - Self and body Tunisian culture:}

Anthropological order concerns the cultural dimension of the body. Mauss (1950) introduced the concept of "body techniques" which means "the ways in which men and society by society traditionally know how to use their bodies". In his book about the body in Islam and the Maghreb, Chebel (1984) shows that "the presence of the body in social space of Maghreb countries is governed by codes that contrast with those of Western countries" (Duret and Roussel, 2003, p. 23).

We check in Tunisian culture, whether these differences are observable about the physical self-concept and highlight the variations that could possibly take over a recurrent feature of the body that runs all the 
dimensions of PSDQ, which highlights its representation based on the mode of having; it is in perfect harmony with the lines marking the western culture companies engaged in the process of streamlining their total instances. Offer to include each of the dimensions and their meanings ideal-typical on a continuum from one pole characterizing these societies; another supposed set companies Arab-Muslim culture.

A duality emerges immediately from the characteristic that passes through all the dimensions of the questionnaire: "having", which corresponds "being". And having a body refers to individuation which proceeds by a series of cuts: the man with himself, with others and with his body. While being a body, means openness to experience that sense, the agreement of man with himself, with others and with his body.

Tunisian culture is it a culture of "being" or "having" or a culture that both modes coexist? It reveals the following questions:

The impact of culture on physical self-concept of young Tunisians did tend to value dimension "being" of the body over that the "having" or "action"? Does it tend to develop the collective dimension at the expense of individual? Finally, does it tend to devalue the status with regard to the intellectual dimension?

\section{Goal}

\section{Methodology}

This work is in the quest for the promotion of the worldviews diversity which must correspond to a cultural adaptation analysis approaches. That's why, we propose to adapt and validate a questionnaire in Arabic on self-esteem, the PSDQ Marsh, inventory hierarchical global self-esteem and the physical domain. This tool consists of 70 items and has 11 scales: 9 specific and 2 overall. The answers are given on a Likert scale to 6 points.

\section{Hypotheses}

1. In the Tunisian culture, an extension with the Arab-Muslim tradition, the body is lived on the mode of being and the relationship, but at the same time on the mode of having and the action.

2. In the Tunisian culture, the body is lived in a rather "collectivist" and appears simultaneously as a factor of individuation.

3. In dealing with the mind, body in Tunisian culture, is part of a hierarchical structure that regulates, while the spirit is exalted. At the same time, this dual structure, reserve a place for a hedonistic conception of the body.

\section{Data analysis}

\section{Results}

The structure of the questionnaire subscales was assessed by factor analysis. At first, we empirically verified the structure in 11 dimensions, 2 globals (the global physical self-concept and general self-esteem) and 9 specific (strength, weight, physical activity, the endurance, athletic competence, coordination, health, appearance and flexibility), announced in the original instrument (Guérin et al. 2004). This should allow to identify items witch, as a matter of translation or understanding, does not regroup under the scale expected. In a second step, the same way that these authors, we analyzed each dimension independently to see if we get also the different sub-dimensions. After checking the internal consistency of each subscale, we evaluated their intercorrelations.

The descriptive statistics of scores at each scale and subscale of the total sample were performed. The test-retest reliability was then assessed by considering the correlations between the scores obtained by the same subjects after a period of 1 month.

\section{Validation of the questionnaire PSDQ in Arabic Construct validity}

Among the important validities to assess when constructing the measuring instrument, we note the construct validity. There are several methods to determine the validity, but the most powerful is the set factor analysis (Kerlinger, 1973).

Also we followed a standard procedure validation (Vallerand et Halliwel, 1983). We have formed a committee to make a translation as faithful as possible items of French language created by Guerin and Famose Marsh (2004).

Some details on the translation process: we opted for the "technical translation parallel blind" (Usunier, 1992), which presents itself as an alternative form of the method of back translation (Vallerand et Halliwel, 1983) or "back-translation ". This, indeed, is not free of problems caused by Ervin (1964, cited by Urien, 2000) that bilingual translators adopt different personalities for different languages, reflecting the dominant value system of the country question. 
Four independent translators were contacted individually: a French teacher in higher education, a professor of Arabic with a good knowledge of French; two teachers from higher institutes of sports and physical education, who have a good knowledge of Arabic. Translated from PSDQ simultaneously and independently, we compared the proposals in presence of the four translators and lead to a consensual choice.

Pre-tests in a population of Tunisian students with a literal translation and a presentation similar to the French inventory, elicited no recurring criticism among respondents. On the merits, the translation has given rise to no loss of meaning. The respondents experienced no constraint semiological to answer the questionnaire translated into Arabic. Thus, the use of the approach in committee she helped us to better preserve the original meaning of the questionnaire Marsh (1986).

In terms of form, the pre-test made from this experiment revealed no difficulty understanding bipolar presentation, following an initial detailed explanation. All items have induced one answer instead of two. Sake of intelligibility of the inventory remained a priority (Comrey, 1988), we chose a Likert scale with 6 increasing degrees (1: False, 2: Overall false, 3: more false than true, 4: more true than false, 5: Overall true, 6: true).

Construct validity is most important to assess during the construction of a measuring instrument. There are several methods to determine the validity, but the most powerful is the set factor analysis (Kerlinger, 1973). Based on the award of the questionnaire to 216 boys and 214 girls, we conducted an exploratory factor analysis to determine the factor structure of PSDQ. We present in Annex the description of this sample.

The exploratory mode is preferred confirmatory method for several reasons, the main one being that, according DeVellis (1991), the factor structure by exploratory method provides more guarantee of validity than the other method because it imposes important restrictions for the analysis. The criterion for the retention factor is the Kaiser (eigenvalue greater than $\square 1.00$ ). We also applied a second Kaiser rule for final selection factors: eliminate factors unintelligible. For statements, we selected those with a weight factor equal to or greater than 0.40. It is important to note that we remove statements that contribute to more than one factor.

\section{Descriptive Statistics}

Table 1 presents the means and standard deviations from this analysis (principal component factor analysis and varimax. orthogonal rotation mode). The final solution consists of 11 factors was tested on a sample of 216 boys and 214 girls.

In our sample, we obtained an average of 4.93 (SD 0.90) for the global physical self-concept and 4.09 (SD 1.13) for self-esteem. The French version validated in a population of 397 adolescents received wide global physical self-concept an average of 4.36 (SD 1.11), and self-esteem scale, an average of 4.72 (SD deviation .89). The main points to note in this regard are as follows (see Table 2): first grouping a set of eight single factors with eigenvalue greater than 1.00 related to the scale of self-esteem. The eight items have coordinates between .55 and .60 on this factor. Second, there is also one factor for the six items of the scale of the global physical self-esteem, whose coordinates are between .59 and .63 .

For the nine specific scales, a model with nine factors accounts for $66.13 \%$ of the total variance (Table 2). The first factor (eigenvalue: $19.08,6.30 \%$ of the total variance) includes eight items of health, the second factor (eigenvalue: $2.50,3.42 \%$ of the variance), the six items of coordination. The third factor (eigenvalue: $2.22,3.30 \%$ of the variance) is mainly represented by six items of physical activity, the fourth factor (eigenvalue: $1.72,2.88 \%$ of the variance) by six items overweight, the fifth factor (eigenvalue: $1.72,2.88 \%$ of the variance) by six items of sports competence, the sixth factor (eigenvalue: $1.41,2.66 \%$ of the variance) by six items of physical appearance, the seventh factor (eigenvalue: $1.36,2.41 \%$ of the variance) by six items of strength, the eighth factor (eigenvalue: $1.30,2.23 \%$ of the variance) by six items of flexibility and ninth (eigenvalue: $1.16,2.08 \%$ of the variance) by six items of endurance.

Given this pre-testing, the draft was tested. It corresponded to a translation closer to the original inventory (70 items, has 11 scales: 9 specific (health, coordination, physical activity, overweight, athletic competence, appearance, strength, flexibility and endurance), and two global (self-concept overall physical and general selfesteem).

In sum, the preliminary version of the questionnaire consists of 70 statements grouped into 11 scales has not undergone any processing. Version of this instrument consists of 70 statements and mesure11 sizes. All this analysis ensures that the questionnaire has a minimum of construct validity, which is very important as psychometric quality. 
Tunisian validation of a measuring instrument: Physical Self-Description Questionnaire (PSDQ)

Table1. Averages, standard deviations, and intern consistence of the obtained results for the 11 scales PSDQ $(N=430)$

\begin{tabular}{|l|c|c|c|c|}
\hline \multicolumn{1}{|c|}{ Dimensions } & Means & standard & $\boldsymbol{\alpha}$ & Test -Retest \\
\hline Health & 3,99 & 1,00 & .80 & .75 \\
\hline Coordination & 5,09 & 0,94 & .79 & .76 \\
\hline Physical Activity & 4,76 & 0,99 & .68 & .80 \\
\hline Embonpoint & 1,99 & 1,05 & .72 & .71 \\
\hline Athletic skill & 4,71 & 0,93 & .76 & .80 \\
\hline appearance & 4,85 & 0,93 & .81 & .79 \\
\hline Force & 4,16 & 0,90 & .74 & .90 \\
\hline Suppleness & 4,78 & 1,00 & .76 & .88 \\
\hline Endurance & 4,09 & 1,14 & .77 & .75 \\
\hline General self-esteem & 4,09 & 1,13 & .79 & .78 \\
\hline General physical & 4,93 & 0,90 & .73 & \\
\hline
\end{tabular}

Table 2: Exploratory Factor Analysis of PSDQ

Factors

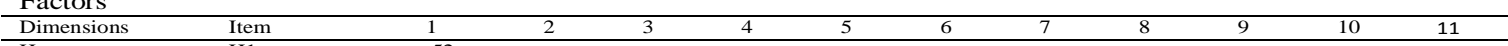

$\begin{array}{ll}\mathrm{H} 1 & .52 \\ \mathrm{H} 12 & .56 \\ \mathrm{H} 23 & .5 \\ \mathrm{H} 34 & .5 \\ \mathrm{H} 45 & .6 \\ \mathrm{H} 56 & .57 \\ \mathrm{H} 67 & .55 \\ \mathrm{H} 69 & .56\end{array}$

\begin{tabular}{llll} 
& $\mathrm{H} 67$ & .55 & \\
& $\mathrm{H} 69$ & .56 & \\
\hline $\mathrm{C}$ & $\mathrm{C} 2$ & & .63 \\
& $\mathrm{C} 13$ & & .61 \\
& $\mathrm{C} 24$ & & .59 \\
& $\mathrm{C} 35$ & & .67 \\
& $\mathrm{C} 46$ & & .65 \\
& $\mathrm{C} 57$ & & .62 \\
\hline
\end{tabular}

\begin{tabular}{lll} 
& C57 & .65 \\
\hline PA & PA 3 & .62 \\
& PA14 & .55 \\
& PA25 & .57 \\
PA36 & .57 \\
& PA47 & .54 \\
& PA58 & .56 \\
\end{tabular}

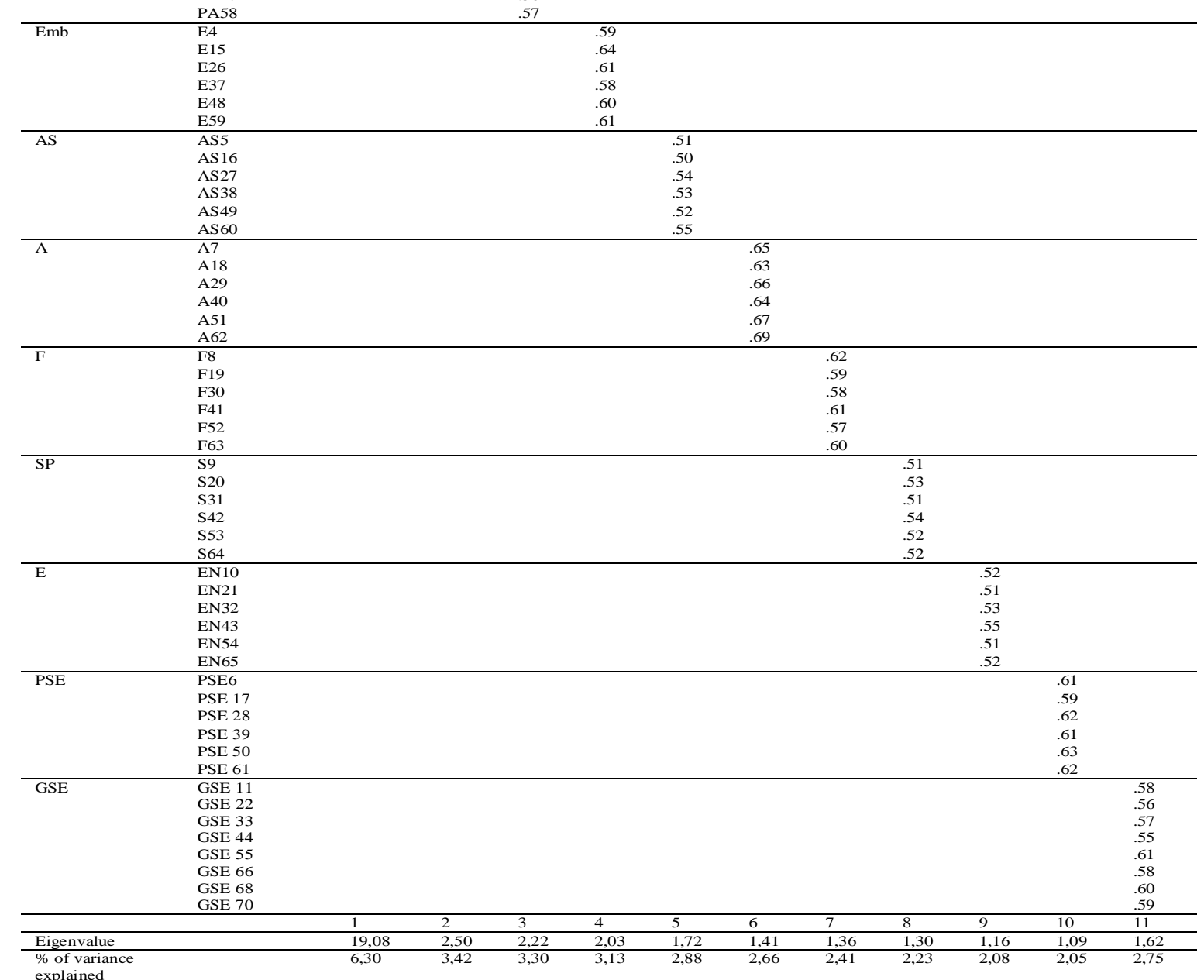


Legend: The experimental PSDQ has 11 scales (GSE = General self-esteem; PSE= Physical self-esteem; Endurance, AS Athletic Skill; A = Appearance; F = Force; Emb = Embonpoint, SP = Suppleness; PA = Physical activity; H= Health; C = Coordination). The meaning of each sentence ( + or -$)$ brings a weight of 1 point (not at all) to 6 points (quite) for positive items and vice versa for negative items. We obtain the mean of each level.

\section{Internal consistency}

When checking metric of a new instrument for measuring quality, it is essential to know the internal consistency of these scales. Table 2 presents the results of the analysis of the internal consistency of the different scales of PSDQ which is calculated by Cronbach's alpha. The Cronbach's alpha coefficients are all above 0.70 , they vary between 0.72 and 0.80 (Table 1), indicating good internal consistency taking into account the number of statements.

Nunnaly and Bernstein (1994) reported that an instrument for development and small scales from three to four statements and an alpha coefficient of 0.70 and most is satisfactory and shows respectable correlations between scales. The test-retest reproducibility is good with interclass correlation coefficients (inter-scale) all above 0.71 [0.71 to 0.90 Overweight dimension to dimension Flexibility] (see Table 2). The level of correlation obtained by orthogonal Varimax rotation indicates a test-retest reliability very satisfactory, as shown in the table 1. In other words, the statements constituting a scale seem to measure the same building or the same phenomenon...

\section{Confirmatory factor analysis}

Exploratory factor analysis allowed us to identify 11 dimensions, which are respectively (2 and 9 overall specific): the global physical self-concept (factor 1), general self-esteem (factor 2), and other factors (health, coordination, physical activity, overweight, sports competence, appearance, strength, flexibility, and endurance). These factors saturate ( $>$.40) six items for the first factor, eight items for the second factor, eight items for the third, six in the fourth factor, six items for the fifth factor, six items for the sixth factor, six items for the seventh factor, six items for the eighth factor, six items for the ninth factor, six items for the tenth factor and six items for the eleventh factor.

Confirmatory analysis in Lisrel 8.3 allowed us to test the experimental version to 70 items assuming the internal structure of this inventory. We conducted the analysis on the basis of the proposed Guerin, Marsh and Famose (2004) hierarchical structure. Against all odds, the model fit is quite satisfactory. The model tested and the results showed a good fit for the advanced analysis of partial correlations and inter-scale data model $(\mathrm{GFI}=$ $.936, \mathrm{AGFI}=.925, \mathrm{IF}=.931, \mathrm{RMSR}=.170 ; 532 /$ degrees of freedom ratio $=1456.38$ ), and show the specificity of the physical appearance domain without rejecting the hierarchical modeling Guerin, Marsh and Famose (2004).

All parameters estimation matrices (load factor, factor variance / covariance and the notions of uniqueness) were positively identified. Factor loadings were statistically significant (.63 to $.93, \mathrm{M}=.85)$ and clearly identified factors that PSDQ was supposed to measure. The correlations between the 11 factors were moderate and ranged from .11 to $.73(\mathrm{M}=.33)$. Among the nine sub-areas, the physical appearance recorded the largest correlation, so she joined the two global factors: the overall physical self-concept, self-esteem, general ( $\mathrm{r}$ $=.73$ and $\mathrm{r}=.51$ respectively).

Then the athletic skill is highly correlated with self-esteem overall physical $(\mathrm{r}=.51)$. However, one can note a clear correspondence on the one hand, between 9 subdomains and secondly, these subdomains and the component of physical self-esteem (average $r=.43$ ). In addition, the overall physical self-esteem has the highest correlation $(\mathrm{r}=.56)$ with the factor of general self-esteem and it shows a lower correlation with the other nine dimensions $(r=.32)$.

As suggested by the theoretical approach, the self-esteem factor was reasonably related to the most specific areas. These relationships between factors provided a strong basis for clearly defined dimensions (see Table 3).

The confirmatory analysis in LISREL 8.3 validates finally the factor structure obtained by Guerin, Marsh and Famose (2004) and does not affect the relationship between the subscales. The internal validity of the tool thus appears satisfactory.

The external validity is tested PSDQ from the links between the global scale self-esteem, self-concept from general physical inventory Marsh (1996), and other scales measured (health, coordination, physical activity, overweight, athletic competence, appearance, strength, flexibility, and endurance). This procedure was also used by Guerin et al, (2004). The results demonstrate strong and hierarchical links between the scales. This analysis provided a good support for a multidimensional physical self-concept. 
Tableau 3

\begin{tabular}{|c|c|c|c|c|c|c|c|c|c|c|c|}
\hline & 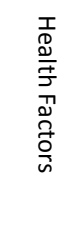 & 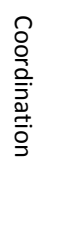 & 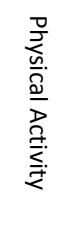 & 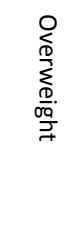 & 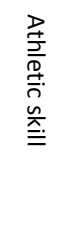 & 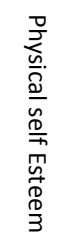 & 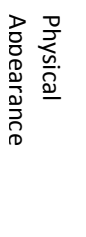 & $\begin{array}{l}\text { ग } \\
\text { ㅁ } \\
0\end{array}$ & 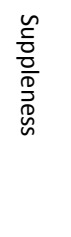 & 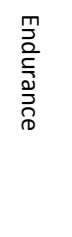 & 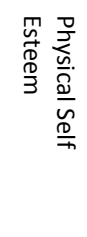 \\
\hline \multicolumn{12}{|l|}{ Indicators } \\
\hline 1 & .78 & .86 & .92 & .87 & .88 & .85 & .90 & .89 & .92 & .91 & .86 \\
\hline 2 & .83 & .91 & .89 & .90 & .92 & .90 & .88 & .90 & .89 & .89 & .82 \\
\hline 3 & .74 & .72 & .83 & .89 & .93 & .91 & .86 & .88 & .90 & .92 & .79 \\
\hline 4 & .63 & & & & & & & & & & 79 \\
\hline \multicolumn{12}{|c|}{ Correlations between factors } \\
\hline Health & 1.00 & & & & & & & & & & \\
\hline Coordination & .31 & 1.00 & & & & & & & & & \\
\hline Physical activity & .16 & .31 & 1.00 & & & & & & & & \\
\hline Embonpoint & .23 & .26 & .25 & 1.00 & & & & & & & \\
\hline Athletic skill & .27 & .48 & .57 & .31 & 1.00 & & & & & & \\
\hline General self esteem & .26 & .38 & .43 & .51 & .51 & 1.00 & & & & & \\
\hline Appearance & .14 & .33 & .25 & .41 & .38 & .73 & 1.00 & & & & \\
\hline Force & .44 & .42 & .49 & .13 & .67 & .52 & .33 & 1.00 & & & \\
\hline Suppleness & .12 & .55 & .31 & .11 & .23 & .21 & .20 & .29 & 1.00 & & \\
\hline Endurance & .15 & .41 & .45 & .35 & .61 & .43 & .25 & .44 & .21 & 1.00 & \\
\hline Physical Self Esteem & .43 & .29 & .23 & .25 & .24 & .51 & .52 & .31 & .19 & .20 & \\
\hline
\end{tabular}

\section{Discussion}

Our study allowed us to find, like the original instrument of Marsh (1996), 11 dimensions as a psychometrical and conceptual point of view.

The psychometric properties of the Arabic version are quite satisfactory in terms of reliability and validity. Moderate but significant correlation between the global scales and scales specific instrument of PSDQ is congruent with the findings of previous studies (see Guerin et al. 2004).

As part of the translation of a ladder, one of the first tracks to be explored is to question the quality of the translation. This question must be especially for items that have not been grouped in an expected manner and not saturate on any of the 11 factors satisfactorily. But this limitation has been overcome in our approach which could be explained by a simple transposition in Arabic to French and English language. This allows us to remain attentive to the difficulty of any translation work, the necessary compromise between literal translation and conceptual relevance, cross-cultural studies have shown that the general physical self-concept may be expressed differently depending on the culture.

What explanation can be given to these results only partially confirm the assumptions that we make? Indeed, the statement of young Tunisians called upon to define their body itself indicates, obviously the results, the convergence of their way to design the physical self with their social formations that are culturally different. Can we say as long as we walked away striding theses of cultural diversity and that we were insensibly towards a world increasingly homogeneous? Also, a serious track immediately offers to us, that considering duels reports Tunisian youth to their body itself.

To support our analysis in this direction, recall that we find in the Arab-Muslim culture traces that reveal a form of spatial control of the body that focuses on have been. In fact, advanced by the religious text metaphor demonstrates the spatial dimension: it states that "the body is like a building whose different joints support each other" (Chebel, 1986, p. 183.). However, do not be evacuated representations of the body. This culture is also related to the happiness of the body.

Ultimately, as Chebel notes in his study of the imaginary Arab-Muslim (1993), "Arab allegiance to several worlds at once, including those of the sacred and profane, equipment and intangible of the thing and its representation. He [...] responds to fundamental dualities "(p. 371). The author concludes that the dual personality of being Arab and Muslim, driven by two opposing forces, transverse and horizontal, which makes difficult the overall synthesis pulling the schizomorphic behavior. It is difficult in this case to say that the design of bodily self is perceived by the Tunisian, depending on the mode of having exclusively, nor on the mode of just being. Based on the analysis of Chebel the two modes could therefore coexist.

\section{Conclusion}

We focused in this work a first draft of a transcultural questionnaire physical self-concept multidimensional and hierarchical validation: the Physical Self-Description Questionnaire (PSDQ) HW Marsh, consisting of eleven particularly significant dimensions of self-concept physical multidimensional and hierarchical childhood. We tested the internal validity (structural) of the questionnaire. The results are consistent 
with the PSDQ validation procedures implemented in the internal validity of the various SDQ and PSDQ (Guerin et al. 2004).

The confirmatory factor analysis showed clearly the 11 components of physical self-concept that is supposed to measure PSDQ. The hierarchical confirmatory factor analysis revealed a general second-order factor. The invariance analysis showed generalization of the factorial structure of PSDQ through the genre. These results have also led to the resolution of a minimum set of problems of internal analysis of the model and should be completed later by a procedure external validity.

In its current state, it could be used for the purposes of basic and applied research in the Tunisian context of sport. This instrument is reliable and valid measure for the design of physical self. It seems useful to examine other samples, further, teens for example, in order to identify new components of self-esteem in adolescence and deepen the study and differential developmental started here.

Conclude with an explanation that aggregates the views advertised on body culture in the Arab-Muslim context and the results of our investigation. The Chebel analyzes (1993) that emphasize the dual personality of Arab-Muslim, can indeed make quite conceivable good coexistence in the Tunisian about dual concepts that can interpenetrate or overlap. In the case of measuring the body PSDQ availability predisposing to sports competition and have erected as a base model to achieve the desired success, we recommend not to lose sight of in the case of Tunisia, with the potential emergence any time, a counter-force to be favoring or any other force that pulls the individual to more hedonistic spheres, imaginary or simply to design a physical self away from concerns of profitability and body control. In sports, we suggest not to consider the connection of the Tunisian symbolic universe duels as a liability or detrimental to the success dissonance, but as an adjuvant can be rewarding its fertility in terms of sporting success.

\section{References}

[1]. BOURDIEU, P. (1992). Réponses. Pour une anthropologie réflexive. Paris: Seuil.

[2]. BOURDIEU, P. (1998). « La domination masculine ». In Actes de Recherche en Sciences Sociales, n 84, septembre 1990, p. 4-31.

[3]. CAMILlERI, C. et. VISONNEAU, G. (1996). Psychologie et culture : concepts et méthodes. Paris: Armand Colin.

[4]. CHEBEL, M. (1984). Le corps dans la tradition au Maghreb. Paris: Presses Universitaires de France.

[5]. CHEBEL, M. (1993). L'Imaginaire arabo-musulman, Paris: Presses Universitaires de France.

[6]. DEVELLIS, R.F., (1991), Scale development: theory and applications, Newbury Park: Sage Publications

[7]. DUDA, J.L. \& ALLISON, M.T., (1990). Cross-cultural analysis in exercise and sport psychology: A void in a field. Journal of Sport and

[8]. Exercise Psychology. 12, 114-131.

[9]. DURET, P. et ROUSSEL, P. (2003). Le corps et ses sociologies. Nathan.

[10]. HABERMAS, J. (1976). Connaissance et intérêt. Paris: Gallimard.

[11]. FAMOSE, J-P. (2001). La Motivation en éducation physique et sport. Paris: Armand Colin.

[12]. GUERIN, F., MARSH, H. W., \& FAMOSE, J-P. (2001). Concept de soi physique : Validation française du PSDQ de Marsh. Actes du congrès de l'ACAPS. Octobre. Valence.

[13]. JODELET, D. (1992). « Enjeux privés et sociaux ». In Le Corps 1, sociétés, sciences, politiques, imaginaires. Belin.

[14]. KERLINGER, F.N., (1973), Foundations of behavioral research, New-York: Holt, Rinehart, \& Winston.

[15]. LE BRETON, D. (1990), Anthropologie du corps et modernité. Paris: PUF.

[16]. MARSH H.W. (1996) Construct validity of Physical Self-Description Questionnaire Responses: Relations to external criteria. Journal of Sport and Exercise Psychology. 18(2): 111-131.

[17]. MAUSS, M. (1950). Sociologie et Anthropologie. Paris: PUF

[18]. MERLEAU-PONTY, M. (1976). Phénoménologie de la perception, Paris: Gallimard.

[19]. NATHAN, T. « Le rôle de Georges Devereux dans la naissance de l'ethnopsychiatrie clinique en France ». In Ethnopsy - Les mondes contemporains de la guérison, $N^{\circ} 1$. février 2000, 197-22

[20]. NUNNALLY, J.C. \& BERNSTEIN, I.H. (1994). Psychometric theory, (3rd Ed.), New-York: McGraw-Hill.

[21]. RICEEUR, P. (2005). «Connaissance de soi et éthique de l'action ». (Entretien avec J. Lecomte). In Sciences Humaines: ${ }^{\circ}$ 162. p.

[22]. SHAVELSON, RJ., HUBNER, JJ. \& STANTON, GC. (1976). Validation of construct interpretations. Review of Educational Research 46: 407-441. Paris: Belin, p. 160.

[23]. URIEN, B. (2000). "Validation d'une échelle de mesure d'une nouvelle dimension temporelle en comportement du consommateur: l'anxiété face à l'avenir". In Convegno " Le tendenze del marketing in Europe". Universita Ca' Foscari. Venezia.

[24]. USUNIER, J-C. (1992). « Commerce entre cultures, une approche culturelle du marketing international ». Collection gestion. PUF.

[25]. VALLERAND, R. J. (1989). Vers une méthodologie de validation trans-culturelle de questionnaires psychologiques : implications pour la recherche en langue française, Psychologie Canadienne, 30, 662-680.

[26]. WEBER, M. (1965). Essais sur la théorie de la science, Paris: Plon. 
Tunisian validation of a measuring instrument: Physical Self-Description Questionnaire (PSDQ)

Physical Self-Description Questionnaire (PSDQ)

(French Version)

\begin{tabular}{|l|l|l|l|l|l|}
\hline Faux & Globalement faux & Plus faux que vrai & Plus vrai que faux & Globalement vrai \\
\hline
\end{tabular}

1 - Quand je tombe malade, je me sens si mal que je ne peux même pas sortir du lit.

2 - Je me sens à l'aise quand j'exécute des mouvements coordonnés.

3 - Plusieurs fois par semaine, je pratique une activité physique ou un sport, suffisamment intensément pour respirer à fond (pour être essoufflé(e)).

$4-$ Je suis trop gros (se).

5 - Les autres pensent que je suis bon(ne) en sport.

6 - Je suis satisfait(e) de ce que je suis physiquement.

7 - Je suis attirant(e).

$8-$ J'ai de la force physique.

9 - Je peux courber, tordre et faire pivoter mon corps assez facilement.

10 - Je peux courir longtemps sans m'arrêter.

11 - Dans ma vie, presque tout ce que je fais se passe bien.

12 - J'ai l'habitude d'attraper la moindre maladie qui traîne (grippe, virus, rhume).

13 - Maîtriser les mouvements de mon corps est facile pour moi.

14 - Je fais souvent de l'exercice physique ou des activités physiques qui me font respirer à fond.

15 - J'ai trop de graisse autour de la taille.

16 - Je suis bon(ne) dans la plupart des sports.

17 - Physiquement, je suis content(e) de moi.

18 J'ai un assez beau visage.

19 - J'ai un corps très puissant.

$20-\mathrm{J}$ 'ai un corps souple.

21 - Je serais bon(ne) dans un test mesurant l'endurance et les efforts physiques prolongés.

22 - Dans ma vie, il y a peu de choses dont je puisse être fier(e).

23 - Je tombe si souvent malade que cela m'empêche de faire tout ce que je veux faire.

24 - Je suis bon(ne) dans les mouvements coordonnés.

$25-3$ ou 4 fois par semaine et pendant au moins 30 minutes, je fais de l'exercice physique ou des activités sportives qui m'essoufflent.

$26-$ J'ai trop de graisse.

27 - Je suis à l'aise dans la plupart des sports.

28 - Je suis satisfait(e) de mon apparence et de mes capacités physiques.

29 - Je suis relativement plus beau(belle) que la plupart de mes ami(e)s.

30 - J'ai plus de force que la plupart des gens de mon âge qui sont du même sexe que moi.

31 - Mon corps est raide et manque de souplesse.

32 - Je pourrais faire un footing de $5 \mathrm{~km}$ sans m'arrêter

33 - Je trouve que ma vie ne sert pas à grand chose.

$34-$ Je suis très rarement malade ou mal fichu(e).

35 - Dans la plupart des activités physiques, j'exécute facilement les mouvements.

36 - Je pratique des activités très physiques (comme par exemple : la course, la danse, le cyclisme,

l'aérobic, la gym ou la natation) au moins 3 fois par semaine.

37 - J'ai des kilos en trop.

$38-$ J'ai de bonnes capacités en sports.

39 - Physiquement, je me sens bien.

$40-$ Je suis moche.

41 - Je n'ai pas beaucoup de force et je ne suis pas musclé(e).

42 - Les différentes parties de mon corps peuvent facilement se plier et bouger pratiquement dans tous les sens.

$43-$ Je pense que je pourrais courir longtemps sans me fatiguer.

44 - Dans la vie, je ne suis bon(ne) à rien.

$45-$ Je tombe souvent malade.

46 - Je trouve que mon corps réalise facilement les mouvements coordonnés.

47 - Je fais beaucoup de sports ou de danse ou de gym' ou d'autres activités physiques.

$48-$ J'ai trop de ventre.

49 - Je suis meilleur(e) en sports que la plupart de mes ami(e)s.

50 - Je suis bien dans ma peau et content(e) de mes capacités physiques.

$51-$ Je suis assez beau(belle).

$52-$ Je serais bon(ne) dans un test de force.

53 - Je pense que je suis suffisamment souple pour la plupart des sports.

54 - Je peux pratiquer pendant longtemps une activité physique sans être fatigué(e).

55 -Dans la vie, la plupart des choses que je fais, je les fais bien.

56 - Quand je tombe malade, je mets longtemps à me rétablir.

57 - Dans les activités physiques et sportives, mes gestes sont élégants et coordonnés.

58 - Je fais du sport ou de l'exercice ou de la danse ou d'autres activités physiques presque tous les jours.

59 - Les autres pensent que je suis gros (se)

$60-$ Je suis bon(ne) en sport.

\begin{tabular}{l}
$61-$ Je suis content(e) de ce que je suis physiquement \\
\hline $62-$ Persone
\end{tabular}

62 - Personne ne me trouve beau (belle).

63 - Je soulève facilement les objets lourds.

$64-$ Je pense que je serais bon(ne) dans un test mesurant la souplesse.

65 - Je suis bon(ne) dans les activités d'endurance comme par exemple : la course de fond, l'aérobic, le

cyclisme, la natation ou le ski de fond.

66 - Dans ma vie, il y a beaucoup de choses dont je peux être fier(e).

67 - Je suis obligé(e) d'aller chez le médecin pour cause de maladie, plus souvent que la plupart des personnes de mon âge.

$68-$ Dans la vie, je rate tout.

69 -Je suis d'habitude en bonne santé, même quand mes ami(e)s tombent malades.

70 - Dans la vie, rien de ce que je fais ne semble aboutir.

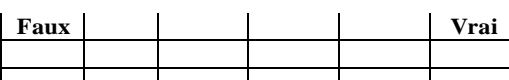

\begin{tabular}{|l|l|l|l|l|l|}
\hline & & & & & \\
\hline
\end{tabular}


Tunisian validation of a measuring instrument: Physical Self-Description Questionnaire (PSDQ)

Physical Self-Description Questionnaire (PSD) Translated into Arabic from the French version استيان حول مفهوم الذات البنني

\begin{tabular}{|c|c|c|c|c|c|c|}
\hline صواب & عموما صواب & الصواب أكثر من الخطأ & 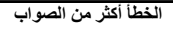 & 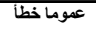 & خطأ & 1- الما أمرض، أشعر بقاق إلى درجة أني اعجز عن مغادرة الفراش \\
\hline & & & & & & 2- 2- أشعر بالارثياح عند القيام بحركات مثتاسقة \\
\hline & & & & & & 3 - أمارس عدة مرات في الأسبوع نشاطا بنيا أو رياضيا بشدة ختى أتنفس بعقى \\
\hline & & & & & & - 4- - إنى سمين جدا \\
\hline & & & & & & - 5- بيتقل الأخرين أنى جيد في الرباضة \\
\hline & & & & & & 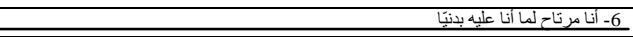 \\
\hline & & & & & & 7- إني جذاب ابر \\
\hline & & & & & & 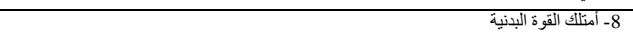 \\
\hline & & & & & & 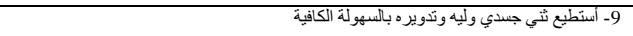 \\
\hline & & & & & & | 10 - أستطيع الجري لددة طويلة بدون توقفن \\
\hline & & & & & & 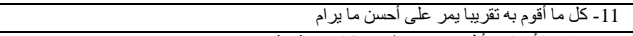 \\
\hline & & & & & & 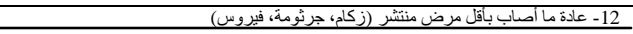 \\
\hline & & & & & & 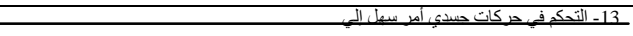 \\
\hline & & & & & & 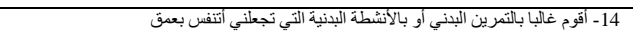 \\
\hline & & & & & & 15 - علدي كثير من الشحم حول الخصر \\
\hline & & & & & & 16 - إني جبل في جلَ الرياضيات \\
\hline & & & & & & 17 - إني راض عن نفسي من حيث اللدن \\
\hline & & & & & & 18 - لاي وجه جميل بما فيهـ الكفاية \\
\hline & & & & & & | 19 لادى جسي قوى جدا \\
\hline & & & & & & 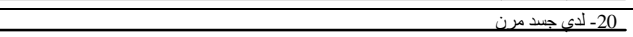 \\
\hline & & & & & & 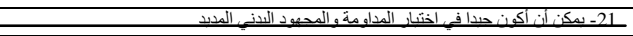 \\
\hline & & & & & & 222 - هناك أتُباء قلبلة في حياتى تجعلني معتز ابنفسي \\
\hline & & & & & & 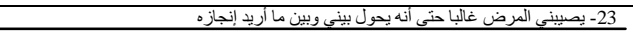 \\
\hline & & & & & & 24- إني أحسن أداء الحر كات المتناسقة \\
\hline & & & & & & اللهئة - أقوم 3 أو4 مرات أسبو عيا لمدة 30د على الأقل، بتمارين بلنية أو أنشطة رياضية إلى حد. \\
\hline & & & & & & 26- في جسمي الكثير من الشحوم \\
\hline & & & & & & 27 - أجد سهولة في أغلب الرياضات \\
\hline & & & & & & 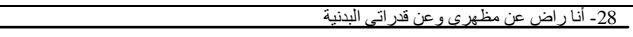 \\
\hline & & & & & & 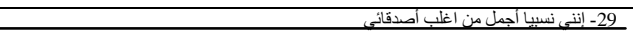 \\
\hline & & & & & & 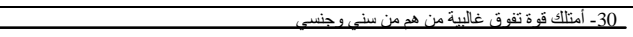 \\
\hline & & & & & & 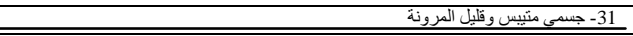 \\
\hline & & & & & & 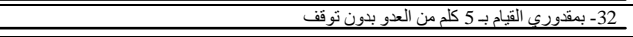 \\
\hline & & & & & & 33 - ارى ان حيائي لا تصلح حسئيء كتير \\
\hline & & & & & & 34 - نادرا ما أمرض أو أكون في حالة صحية سيئة \\
\hline & & & & & & 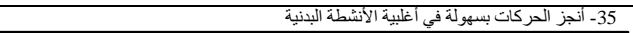 \\
\hline & & & & & & 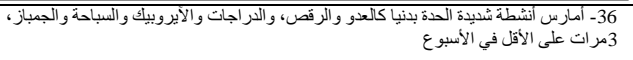 \\
\hline & & & & & & - 37 - جسمي زائد الوزن \\
\hline & & & & & & 38 - لاي فلدرات حسنة في الرياضات \\
\hline & & & & & & 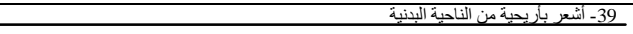 \\
\hline & & & & & & 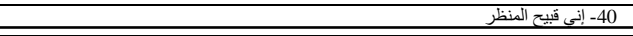 \\
\hline & & & & & & 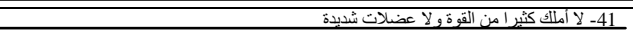 \\
\hline & & & & & & 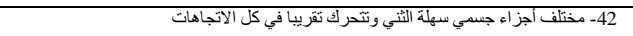 \\
\hline & & & & & & 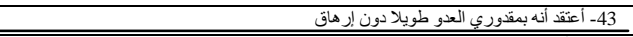 \\
\hline & & & & & & 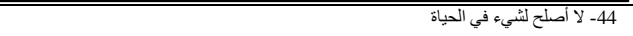 \\
\hline & & & & & & 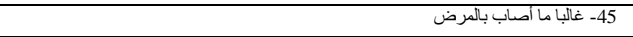 \\
\hline & & & & & & ب 46- أرى أن جسمى يؤدى حركات متناسقة بهولة \\
\hline & & & & & & 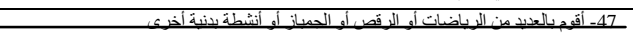 \\
\hline & & & & & & 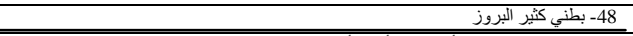 \\
\hline & & & & & & 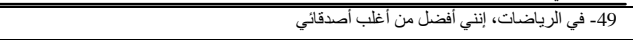 \\
\hline & & & & & & 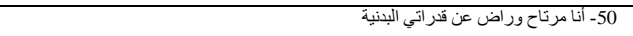 \\
\hline & & & & & & | 51- أنا جميل بالصورة الكافية \\
\hline & & & & & & 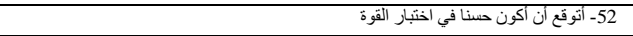 \\
\hline & & & & & & 253- أعتفل أنتي مرن بما فيه الكفاية في جل الرياضات \\
\hline & & & & & & 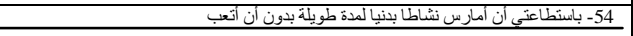 \\
\hline & & & & & & 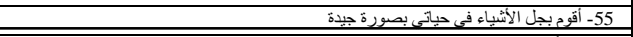 \\
\hline & & & & & & 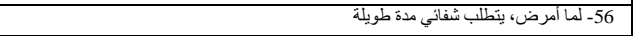 \\
\hline & & & & & & |57- إن حر كاتي في الأنشطة البنئية والرياضية أنيقة ومتثناسقة \\
\hline & & & & & & 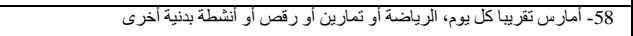 \\
\hline & & & & & & 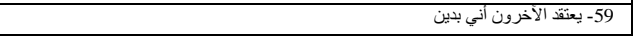 \\
\hline & & & & & & - 60 - أنا حسن في الرياضة \\
\hline & & & & & & 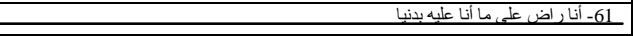 \\
\hline & & & & & & 年 \\
\hline & & & & & & 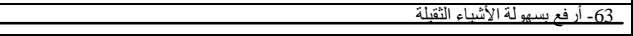 \\
\hline & & & & & & 64 - اتوقع ان أكون حسنا في اختبار المرونة \\
\hline & & & & & & 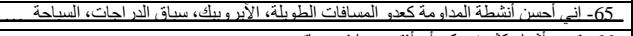 \\
\hline & & & & & & 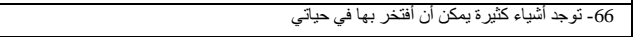 \\
\hline & & & & & & 67 - 67- اضطر للأهاب إلى الطبيب بسبب المرض اكتر من غلليية من هم في سني \\
\hline & & & & & & 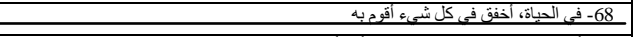 \\
\hline & & & & & & 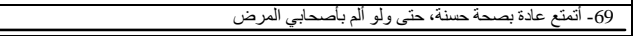 \\
\hline & & & & & & 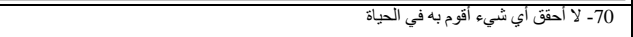 \\
\hline
\end{tabular}

